\title{
Estimasi dan Evaluasi Debit Rembesan pada Bendungan Urugan Batu Zonal Inti Tegak
}

\author{
Siswanto 1), Suprapto ${ }^{2)}$, Sri Sangkawati Sachro ${ }^{3)}$ \\ ${ }^{1}$ Dinas PU Sumber Daya Air Provinsi Jawa Timur, \\ 2 Politeknik Pekerjaan Umum, Semarang \\ ${ }^{3}$ Departemen Teknik Sipil, Universitas Diponegoro, Semarang
}

email: siwato@gmail.com

\begin{abstract}
ABSTRAK
Bendungan urugan batu zonal inti tegak mempunyai geometri yang lebih kompleks dibandingkan dengan bendungan tanah homogen. Banyaknya bentuk geometri dan material yang digunakan menyebabkan prediksi dan perhitungan yang lebih rumit. Pemodelan finite element (FEM) sering digunakan untuk menghitung perilaku rembesan yang terjadi. Tujuan dari penelitian ini adalah untuk mendapatkan model numeris yang dapat digunakan sebagai estimasi debit rembesan sekaligus sebagai validasi pemodelan rembesan pada bendungan urugan batu inti tegak. Evaluasi debit berdasarkan pengukuran instrumen diperlukan untuk validasi pemodelan numeris yang dilakukan. Hukum Darcy dan Casagrande dapat digunakan untuk mengevaluasi pola debit terukur. Debit rembesan berbanding lurus dengan ketinggian muka air waduk dan berbanding terbalik dengan panjang lintasan rembesan. Metode statistik dan regresi digunakan untuk mendapatkan pola rembesan berdasarkan akuisisi data rembesan melalui V-Notch. Estimasi dan pola rembesan ini penting untuk diketahui, sehubungan dengan kinerja electronic instrument yang berpotensi mengalami kerusakan dan sulitnya akses pada gallery karena suatu keadaan. Studi kasus pada paper ini dilakukan pada Bendungan Jatibarang (Semarang), dimana bendungan ini mulai beroperasi penuh pada tahun 2015. Inkonsistensi data debit rembesan terjadi sampai dengan 3 tahun setelah penggenangan bendungan dilakukan. Pola linier hubungan debit rembesan (q) berdasarkan ketinggian muka air waduk (h) yaitu $\mathrm{q}=0.5221 \mathrm{~h}-68.958$. Koefisien determinasi pada model tersebut sebesar 78.5\%, nilai ini mengindikasikan bahwa model tersebut sudah cukup baik untuk digunakan. Pendekatan ini dapat digunakan sebagai validasi data pada semua jenis pemodelan sesuai dengan tujuan pemodelan tersebut akan dilakukan.
\end{abstract}

\section{Kata Kunci : rembesan; bendungan urugan batu; v-notch}

\begin{abstract}
Vertical zoned rockfill dam has a more complex geometry compared to a homogeneous earthfill dam. The many geometric shapes and materials used to cause more complex predictions and calculations. Finite element (FEM) modeling is often used to calculate seepage behavior. The purpose of this study is to obtain a numerical model that can be used to estimate of seepage discharge and as validation of seepage modeling on zoned vertical rockfill dam. Seepage evaluation based on instrument measurements is needed for validation of numerical modeling performed. Dary's and Casagrande's Law can be used to evaluate the measured discharge pattern. The seepage discharge is directly proportional to the height of the reservoir water level and inversely proportional to the length of the seepage path. Statistical and regression methods are used to obtain the seepage pattern based on seepage data acquisition using $V$-Notch. Estimation and seepage pattern is important to know due to the performance of electronic instruments that have potential damage and difficult access to the gallery. The case study in this paper was carried out at the Jatibarang Dam (Semarang), where the dam began full operation in 2015. The inconsistency of seepage discharge data occurred up to 3 years after the impounding of the dam. The linear pattern of seepage discharge relationship (q) based on reservoir water level (b) is $q=0.5221 \mathrm{~h}-68.958$. The coefficient of determination in the model is $78.5 \%$, this value indicates that the model is good enough to be used. This
\end{abstract}

Cara Mengutip : Siswanto, Suprapto, Sachro, S. S. (2019). Estimasi dan Evaluasi Debit Rembesan pada Bendungan Urugan Batu Zonal Inti Tegak. Reka Buana : Jurnal Ilmiah Teknik Sipil dan Teknik Kimia, 4(2), 129138. http://dx.doi.org/10.33366/rekabuana.v4i2.1424 
approach can be used for data validation on all types of modeling in accordance with the purpose of the modeling will be carried out.

\section{Keywords: seepage; rockfill dam; v-notch}

\section{PENDAHULUAN}

Mayoritas bendungan di Indonesia dibuat dengan tipe urugan, baik urugan batu maupun urugan tanah. Hal ini berkaitan dengan kondisi geologi dan ketersedian material yang ada. Bendungan tipe urugan sangat rawan terhadap longsoran dan rembesan. Berdasarkan data yang ada, faktor rembesan menyumbang $25 \%$ terhadap kegagalan bendungan [1]. Rembesan ini menempati urutan pertama kategori penyebab kegagalan bendungan [2]. Faktor penyebab kegagalan bendungan lainnya yaitu limpasan, rembesan, kebocoran pipa saluran, kerusakan timbunan bagian hulu, stabilitas lereng dan penyebab lainnya (gempa, likuifaksi, sabotase dll). Evaluasi keamanan bendungan dapat menggunakan metode indeks resiko atas berbagai faktor penyebab kegagalan bendungan tersebut [3].

Secara statistik, probabilitas terjadinya kegagalan bendungan pada umur 0-5 tahun sebesar 50\% dari 0-100 tahun setelah impounding. Oleh karenanya perencanaan dan monitoring pada tahap awal sangat penting dilakukan untuk mendapatkan karakteristik dan perilaku bendungan terhadap gerakan dan aliran sejak dini.

Manfaat dan potensi resiko bendungan yang besar ini memicu perubahan desain bendungan menjadi beragam untuk berbagai kondisi dan tujuan. Dari bendungan urugan tanah homogen sederhana (Gambar 1) menjadi bendungan urugan zonal yang terdiri dari berbagai kombinasi geometri dan jenis material [4].

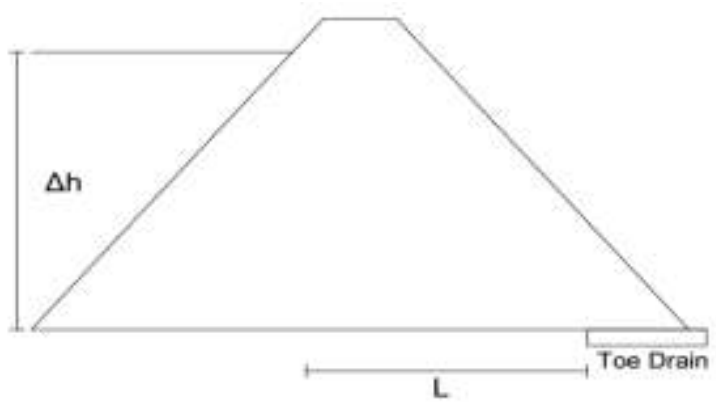

Gambar 1. Tipikal bendungan tanah homogen

Penamaan tipe bendungan urugan pada umumnya berdasarkan desain geometri drainase dan inti bendungan. Tujuan utama dari berbagai desain yang ada untuk mendapatkan desain yang aman dan ekonomis [5]. Secara umum bendungan urugan batu (Gambar 2) terdiri atas 3 bagian utama yaitu shell (upstream/downstream), core dan drain. Berbeda dengan bendungan tanah homogen yang hanya terdiri dari material tunggal, sehingga lebih mudah analisa dan pemodelannya. Kompleksitas pemodelan rembesan dibarengi dengan hasil yang tidak sepenuhnya akurat. Sehingga berbagai pendekatan perhitungan terus dilakukan. Untuk memastikan keamanan bendungan maka diperlukan instrumen untuk memonitor perilaku bendungan [6].

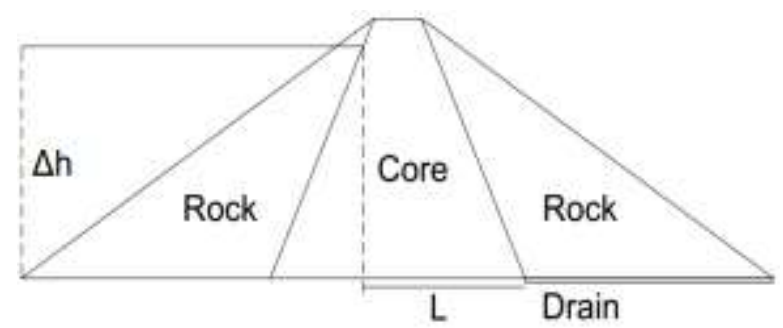

Gambar 2 Tipikal bendungan urugan batu inti tegak 
Berbagai perilaku bendungan sebagai respon terhadap gerakan dan aliran yang dapat membahayakan bendungan dimonitor dengan berbagai instrumen yang sesuai. Perkembangan teknologi yang ada menjadikan sensor instrumen semakin sensitif, otomatis dan akuisisi dapat dilakukan secara remote tanpa perlu melakukan pengamatan langsung pada lokasi instrumen berada [7]. Kelemahan dari instrumen elektronik ini adalah rawan terhadap kerusakan baik pada perangkat kerasnya yang rentan, sistem transmisi data (wired/wireless) ataupun akibat adanya arus pendek [8].

Debit rembesan dapat diketahui dengan memasang Seepage Masurement Instrument (SMI). Dengan memasang instrument tersebut kita akan mendapatkan data secara paralel antara debit rembesan (q) dengan elevasi muka air waduk (h). Data rembesan ini sangat penting untuk evaluasi keamanan bendungan dan pemodelan lainnya. Seperti pada bendungan Jatibarang, beberapa bendungan serupa menempatkan berbagai instrumen penting kedalam gallery. Hal ini akan lebih praktis dan aman dari vandalisme seperti kebanyakan instrumen yang rusak atau hilang pada bendungan tanpa gallery [9]. Meskipun demikian, tetap diperlukan metode lainnya sebagai back-up data seandainya dikarenakan kerusakan alat, atau suatu kondisi dan sesuatu terjadi yang memaksa operator tidak dapat mengakses gallery untuk akuisisi data [10].
Dikarenakan pentingnya data debit rembesan terukur, maka diperlukan analisis untuk mengetahui pola rembesan dan estimasi debit rembasan yang terjadi. Penelitian ini menggunakan Bendungan Jatibarang sebagai model yang akan dievaluasi. Bendungan Jatibarang merupakan bendungan urugan batu zona inti tegak di bawah wewenang Balai Besar Wilayah Sungai Pemali Juana, Kementerian PUPR. Output dari penelitian ini berupa model numeris yang dapat digunakan untuk estimasi rembesan (q) pada sembarang elevasi muka air waduk (h). Penelitian ini merupakan bagian dari penelitian analisis rembesan pada bendungan urugan batu zona inti tegak untuk mendapatkan hubungan antara berbagai rasio parameter rembesan yang dapat diestimasikan pada bendungan tipe serupa.

\section{METODE PENELITIAN}

Bendungan Jatibarang merupakan bendungan urugan batu zona inti tegak yang berada di Semarang, Indonesia. Bendungan ini dibangun pada tahun 2008 dan mulai impounding tahun 2014 dan resmi beroperasi pada tahun 2015. Geometri, penggunaan material yang beragam (Gambar 3) dan berlokasi pada area geologi sesar membuat analisis rembesan menjadi tidak mudah. Parameter material yang digunakan pada bendungan jatibarang dapat dilihat dalam Tabel 1. [11].

Tabel 1. Parameter material di bendungan Jatibarang

\begin{tabular}{|c|c|c|c|c|c|c|c|c|c|}
\hline No & Parameter & Unit & Impervious & $\begin{array}{l}\text { Fine } \\
\text { Filter }\end{array}$ & $\begin{array}{c}\text { DS } \\
\text { Coarse } \\
\text { Filter } \\
\end{array}$ & $\begin{array}{c}\text { US } \\
\text { Coarse } \\
\text { Filter } \\
\end{array}$ & $\begin{array}{c}\text { Inner } \\
\text { Pervious }\end{array}$ & $\begin{array}{l}\text { Outer } \\
\text { Pervious }\end{array}$ & Bedrock \\
\hline 1 & Spesific grafity $(G s)$ & & 26.27 & 25.30 & 24.91 & 25.10 & 24.91 & 24.91 & 23.81 \\
\hline 2 & $\begin{array}{l}\text { Berat Volume Kering } \\
\left(\gamma_{d y}\right)\end{array}$ & $\mathrm{kN} / \mathrm{m}^{3}$ & 18.34 & 18.24 & 18.83 & 20.40 & 18.83 & 18.83 & 20.12 \\
\hline 3 & $\gamma_{\text {sat }}$ & $\mathrm{kN} / \mathrm{m}^{3}$ & 21.48 & 20.99 & 21.18 & 22.26 & 21.80 & 21.18 & 21.82 \\
\hline 4 & $\gamma_{w e t}$ & $\mathrm{kN} / \mathrm{m}^{3}$ & 20.69 & 18.63 & 19.02 & 20.69 & 19.20 & 19.20 & 20.12 \\
\hline 5 & Kohesi (c) & $\mathrm{KN} / \mathrm{m}^{2}$ & 9.81 & 0.001 & 0.001 & 0.001 & 0.001 & 0.001 & 680 \\
\hline
\end{tabular}




\begin{tabular}{|c|c|c|c|c|c|c|c|c|c|}
\hline 6 & Sudut geser dalam $(\phi)$ & o & 25 & 35 & 35 & 35 & 42 & 42 & 55 \\
\hline 7 & Angka pori (e) & - & 0.923 & 0.390 & 0.390 & 0.390 & 0.325 & 0.325 & \\
\hline 8 & Water content (w) & - & $15.50 \%$ & $2.00 \%$ & $2.00 \%$ & $2.00 \%$ & $1.00 \%$ & $1.00 \%$ & \\
\hline 9 & Koefisien permeabilitas & $\mathrm{cm} / \mathrm{dt}$ & $1 \times 10^{-5}$ & $3 \times 10^{-3}$ & $1 \times 10^{-2}$ & $1 \times 10^{-2}$ & & & $2.7 \times 10^{-4}$ \\
\hline
\end{tabular}

Terdapat dua V-Noth, Seepage Measurement Instrument (SM), utama pada bendungan Jatibarang. SM1 mengukur rembesan pada kiri galeri dan SM2 mengukur debit rembesan pada kanan galeri. Kedua VNotch ini diletakkan dalam gallery dan diukur bersamaan. Dalam analisis debit kedua hasil pengukuran ini dijumlahkan sebagai debit rembesan total. Akuisi data pada instrument ini dapat menggunakan 2 cara yaitu otomatis (remote) dan manual sebagai pembandingnya.

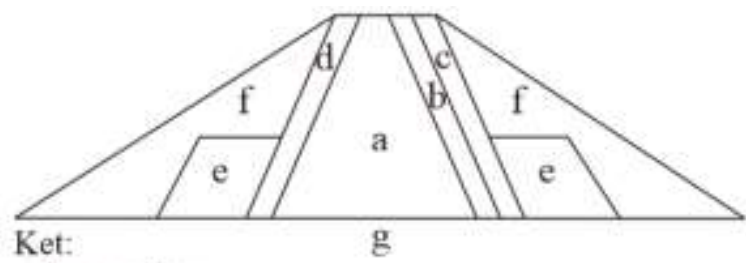

a: Impervious

b: Fine Filter

c: Down Stream Coarse Filter

d: Up Stream Coarse Filter

e: Inner Pervious

f: Outer Pervious

g: Bed Rock:

Gambar 3. Geometri dan jenis material di bendungan Jatibarang

Jenis material pada masing-masing zona dan fungsinya (Tabel 1) adalah sebagai berikut:

a. Impervious Zone (Zona Kedap)

Impervious Zone merupakan zona inti yang berfungsi sebagai zona kedap air. Zona ini tersusun dari urugan lempung lunak dengan plastisitas tinggi. Angka pori (e) pada zona ini adalah 0,923 dengan water content (w) sebesar $12.6 \%$.

b. Fine Semi Pervious Zone (Zona Filter)

Berdasarkan desain yang ada, material pada zona ini terdiri lapisan pasir sedang berkerikil halus yang lolos saringan No.4 $(4,76 \mathrm{~mm})$. Zona ini berfungsi sebagai saringan (filter) aliran dari zona inti sebelum dialirkan melalui drain. Sehingga material inti tidak ikut larut dan terbawa aliran.

c. Coarse Semi Pervious Zone (Zona Transisi)

Zona transisi terpasang pada hulu zona inti dan hilir zona filter. Material pada zona ini terdiri atas kerikil dengan diameter tidak lebih dari $60 \mathrm{~cm}$ dan material pasir dengan ukuran $25 \mathrm{~mm}$ kurang dari $40 \%$. Zona transisi berfungsi sebagai drain jika ada aliran rembesan yang tembus ke melewati zona filter, sehingga tekanan air pori dapat segera dilepaskan. Selain itu juga berfungsi sebagai transisi dari material halus ke material dengan diameter cukup besar sehingga bendungan lebih stabil.

\section{d. Inner Pervious Zone}

Material pada zona ini terdiri atas batuan dengan diameter tidak lebih dari $60 \mathrm{~cm}$. Zona ini berfungsi sebagai tambahan stabilitas bendungan pada tahap konstruksi.

e. Outer Pervious Zone (Zona urugan batu)

Material pada zona ini berasal dari batuan breksi. Diameter maksimum $100 \mathrm{~cm}$ dan butiran lebih kecil dari $25 \mathrm{~mm}$ tidak lebih dari 30\%. Rip-rap dipasang pada permukaan urugan batu setebal $2 \mathrm{~m}$. Dalam pemodelan pada penelitian ini, material urugan rip-rap disamakan dengan zona urugan batu karena mempunyai persamaan parameter.

f. Bed Rock (Batuan Pondasi)

Berdasarkan hasil pressure test batuan pondasi berada dalam range 5-20 Lugeon. Angka ini cukup besar sehingga diperlukan curtain grouting dibagian bawah pondasi bendungan. 
g. Curtain Grouting (Grouting Tirai)

Grouting tirai mempengaruhi panjang lintasan rembesan pada pondasi, oleh kerana itu penting untuk dimasukkan dalam analisa rembesan. Curtain grouting disyaratkan mempunyai nilai lugeon $<5$.

\subsection{Rembesan pada bendungan}

Metode flownet berdasarkan Hukum Darcy dan Casagrande mengindikasikan bahwa debit rembesan berbanding lurus dengan elevasi muka air waduk dan kemiringan hidrolisnya. Namun demikian, data rembesan bendungan pada fase awal tidak sepenuhnya mematuhi hukum dasar ini.
Hal ini berkaitan dengan kondisi batas dan tekanan air pori pada tubuh bendungan sesaat pasca konstruksi dan awal penggenangan. Data debit rembesan melalui V-Notch ini tidak dapat digunakan sebagai acuan estimasi debit rembesan sampai didapatkan hasil data yang konsisten dan mempunyai pola yang relatif tidak bertentangan dengan Hukum Darcy. Data tersebut juga tidak bisa digunakan sebagai validasi (benchmark) pemodelan lainnya. Oleh karenanya diperlukan pemilahan dan pemilihan data terlebih dahulu. Proses pemilihan hingga menjadi model matematis dapat dilihat pada Gambar 4.

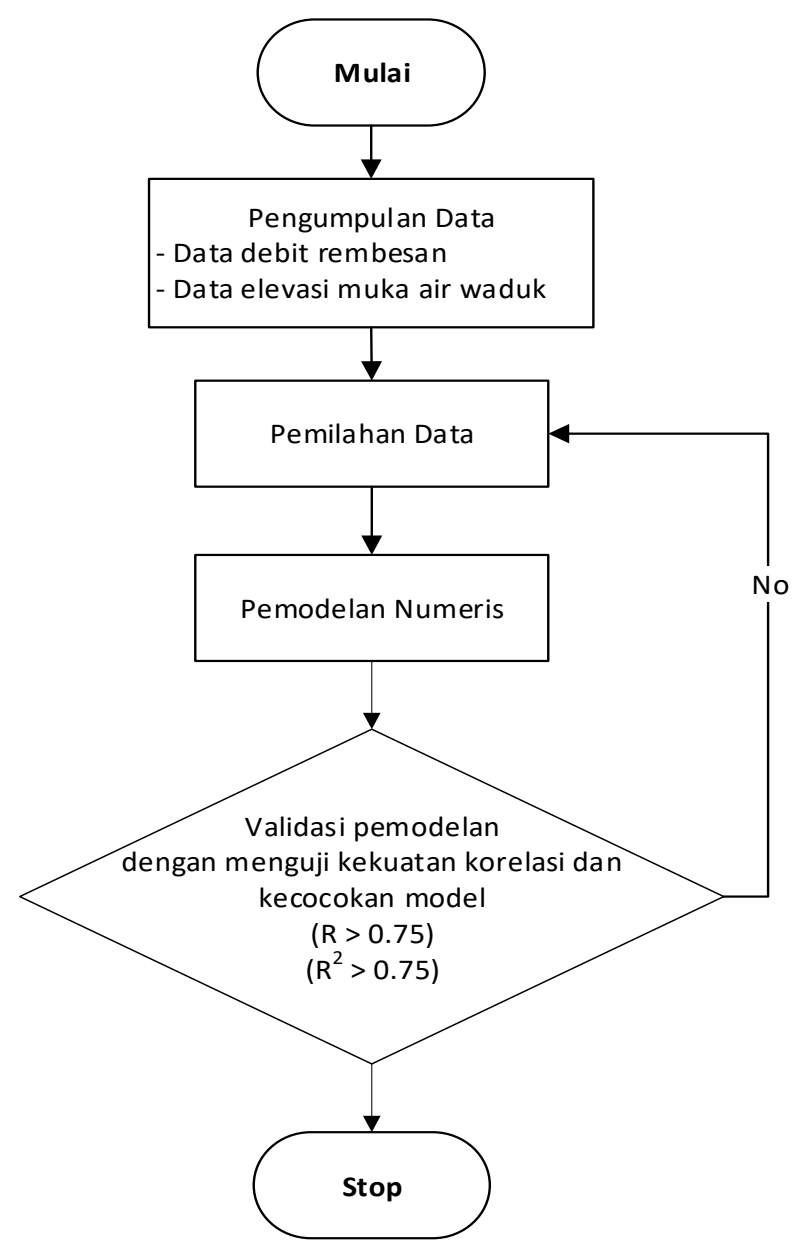

Gambar 4. Tahapan penelitian 


\subsection{Pemilahan data}

Konsep utama dalam pemilahan data debit melalui v-notch adalah berdasarkan konsistensi data debit yang searah (berhubungan positif) dengan elevasi muka air waduk. Jika terdapat data yang tidak relevan maka data tersebut tidak dimasukkan dalam analisis debit acuan. Anomali tersebut bukan disebabkan karena kesalahan pengukuran semata tetapi lebih dominan disebabkan penyesuaian instrumen dan perilaku tekanan air pori yang belum stabil pada tubuh bendungan.

Pengamatan data dilakukan mulai dari impounding (tahun 2014) sampai dengan data terakahir yang didapat (tahun 2018). Evaluasi rembesan pada bendungan berusia muda ini mutlak dilakuka untuk mendapatkan data perilaku bendungan sejak bendungan tersebut dioperasikan. Metode statistik regresi digunakan untuk membuat model numeris estimasi debit rembesan (q) pada sembarang elevasi muka air waduk (h). Pada umumnya regresi polinomial akan menghasilkan koefisien determinasi $\left(\mathrm{R}^{2}\right)$ lebih baik dibandingkan dengan regresi linier, tetapi untuk tujuan praktis regresi linier akan lebih mudah untuk digunakan. Model numeris yang dibuat akan diuji kekuatan, arah dan kecocokan modelnya dengan data yang tersedia, proses analisis tersebut dapat dilihat dalam Gambar 4.

Besarnya koefesien korelasi (R) berkisar antara $+1 \mathrm{~s} / \mathrm{d}-1$. Koefesien korelasi menunjukkan kekuatan (strength) hubungan linear dan arah hubungan dua variabel acak. Jika koefesien korelasi positif, maka kedua variabel mempunyai hubungan searah. Artinya jika nilai variabel $\mathrm{X}$ tinggi, maka nilai variabel $Y$ akan tinggi pula. Sebaliknya, jika koefesien korelasi negatif, maka kedua variabel mempunyai hubungan terbalik. Artinya jika nilai variabel $\mathrm{X}$ tinggi, maka nilai variabel $\mathrm{Y}$ akan menjadi rendah (dan sebaliknya). Interpretasi nilai koefisien korelasi dapat dilihat dalam Tabe1 2 [12].

Selain koefisien korelasi (R), koefisien determinasi $\left(\mathrm{R}^{2}\right)$ juga diperlukan untuk melihat sejauh mana tingkat kecocokan suatu model. Regresi $\mathrm{R}^{2}$ ini dijadikan sebagai pengukuran seberapa baik garis regresi mendekati nilai data asli yang dibuat model. Jika $\mathrm{R}^{2}$ sama dengan 1, maka angka tersebut menunjukkan garis regresi cocok dengan data secara sempurna.

Tidak ada nilai negatif untuk nilai koefisien determinasi, karena hubungan antar variabel bebas (independent) dengan variabel tak bebasnya (dependent). Jika nilai $\mathrm{R}^{2}=1$ adalah model yang sempurna, maka model dikatakan baik jika mempunyai nilai $\mathrm{R}^{2}$ antara 0.6-0.8 dan dikatakan sangat baik jika $R^{2}>0.8$ [13].

Tabel 2. Koefisien korelasi (R)

\begin{tabular}{cc}
\hline Nilai & Koefisien Korelasi $(\mathrm{R})$ \\
\hline 0 & Tidak berkorelasi \\
$0-0.25$ & Korelasi sangat lemah \\
$0.25-0.5$ & Korelasi cukup \\
$0.5-0.75$ & Korelasi kuat \\
$0.75-0.99$ & Korelasi sangat kuat \\
1 & Berkorelasi sempurna \\
\hline
\end{tabular}

\section{HASIL DAN PEMBAHASAN}

Data debit rembesan V-Notch (SM1+SM2) dan elevasi muka air waduk yang terverivikasi lengkap dari tahun 2014 s.d 2018 terekam sebanyak 611 data series. Grafik hubungan antara debit rembesan (q) dan elevasi muka air waduk (h) dapat dilihat dalam Gambar 5. 


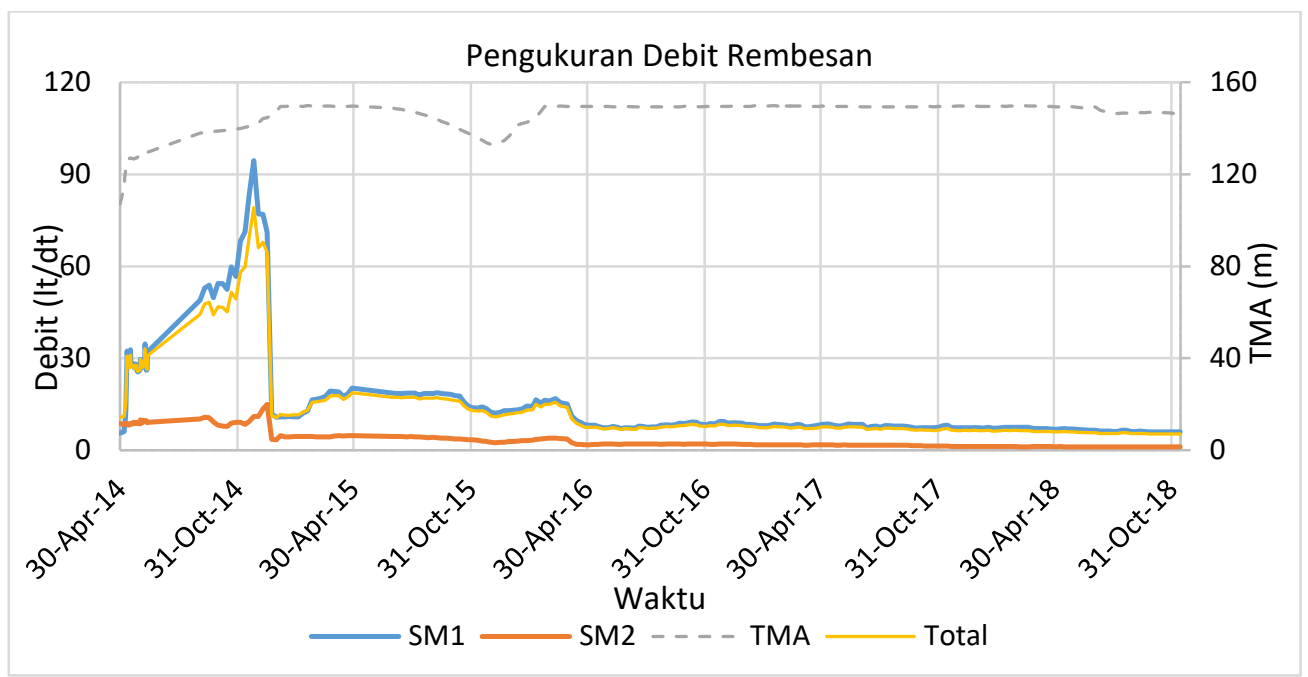

Gambar 5. Pengukuran debit rembesan melalui V-Notch

Tinggi muka air waduk mempunyai pengaruh besar terhadap debit rembesan yang terjadi. Prinsip dasar yang digunakan adalah elevasi muka air waduk mempunyai korelasi positif terhadap debit rembesan terukur. Pada data yang ada, terdapat ketidak teraturan hubungan debit rembesan dengan elevasi muka air waduk pada pengisian awal waduk tahun 2014 hingga tahun 2016. Dua hingga tiga tahun pertama sejak impounding, data debit rembesan belum mempunyai pola yang konsisten. Data tersebut tidak menghasilkan korelasi yang jelas antara ketinggian muka air waduk dengan debit rembesan yang terjadi.
Konsistensi data didapatkan mulai pada tahun 2017 hingga akuisisi data terakhir. Oleh karenanya data terpilih inilah yang selanjutnya digunakan sebagai dasar pemodelan numeris. Grafik data rembesan terpilih pada Gambar 6 terlihat bahwa ketika elevasi muka air waduk pada kondisi steady dan fluktuasi elevasinya kecil, maka debit v-notch mengalami perubahan yang tidak teratur (inkonsisten). Ketika elevasi muka air waduk berubah secara gradual dalam waktu yang lama dengan range perubahan yang besar terlihat lebih berpola yang dapat digunakan untuk pembanding (bench mark) atau kepentingan operasional lainnya.

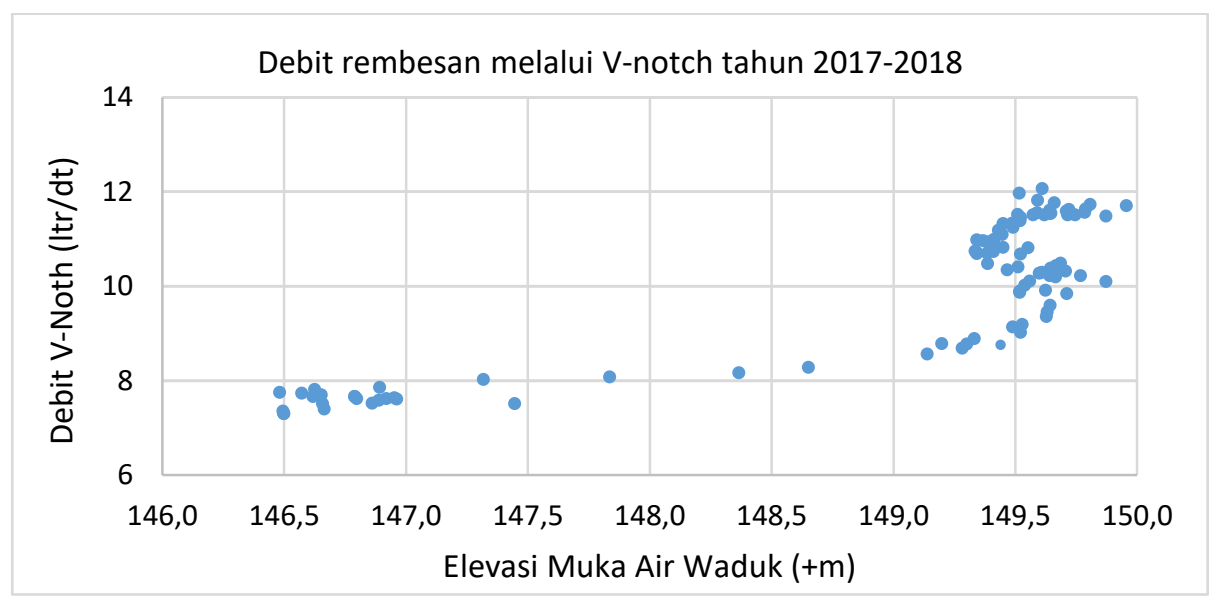

Gambar 6. Debit rembesan terpilih 
Data tahun 2017-2018 yang tersaji dalam Gambar 6, dilakukan pemilihan data ke-2 untuk memperhalus hasil debit yang akan dijadikan model matematis menggunakan metode regresi polinomial dan regresi linier. Koefisien korelasi (R) yang didapatkan dari pemodelan ini adalah 0.958 untuk regresi polinomial (Gambar 7) dan 0.886 untuk regresi linier (Gambar 8). Berdasarkan nilai tabel kekuatan korelasi pada (Tabel 2) dan hasil yang didapatkan dari pemodelan (Tabel 3), kedua model numeris ini mempunyai nilai $\mathrm{R}$ antara 0.75-0.99. Hal ini mengindikasikan bahwa kedua model matematis ini mempunyai korelasi positif yang sangat kuat antara variabel (h) terhadap (q). Tingkat kecocokan model dengan data acuan masingmasing secara berurutan termasuk dalam kategori baik dan sangat baik untuk regresi linier dan polinominal. Menimbang faktor kepraktisan di lapangan dan hasil uji korelasi yang ada, model linier lebih tepat untuk digunakan. Model linier juga relatif punya kecocokan tanpa batas atas atau batas bawah.

Tabel 3. Perbandingan parameter $\mathrm{R}$ dan $\mathrm{R}^{2}$ pada model linier dan polinomial orde 2

\begin{tabular}{ccc}
\hline Parameter & Linier & $\begin{array}{c}\text { Polinomial Orde } \\
2\end{array}$ \\
\hline $\mathrm{R}$ & 0.886 & 0.958 \\
$\mathrm{R}^{2}$ & 0.7848 & 0.9178 \\
\hline
\end{tabular}

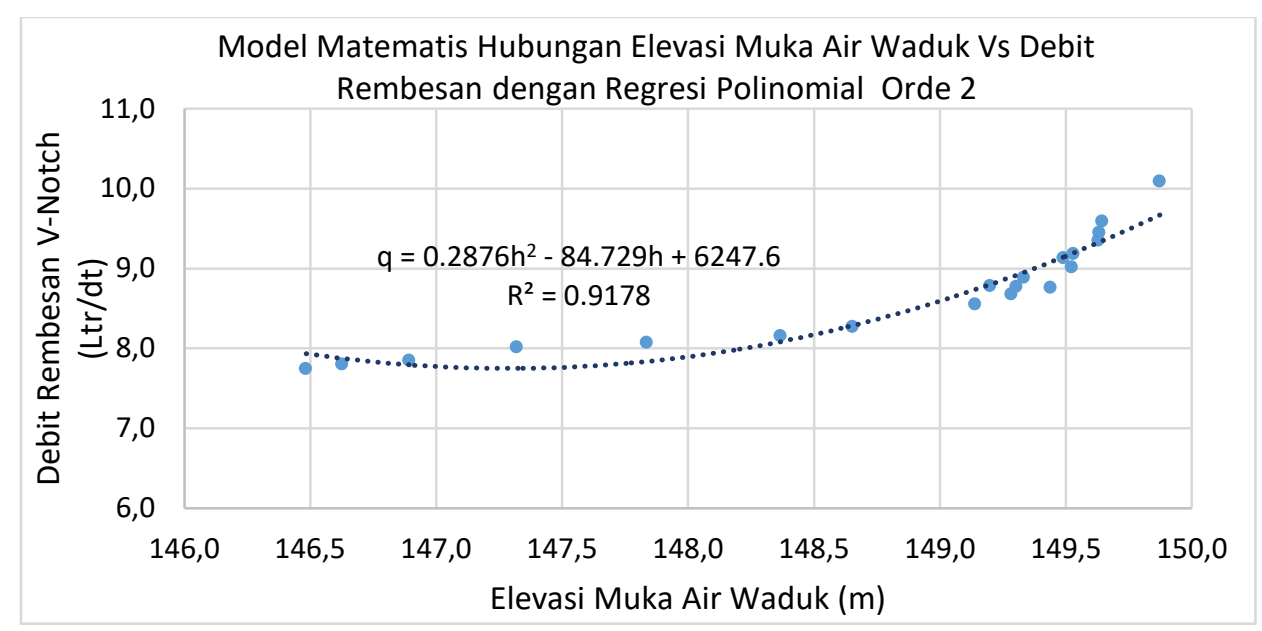

Gambar 7. Regresi Polinomial Hubungan Antara Debit Rembesan dengan Elevasi Muka Air Waduk

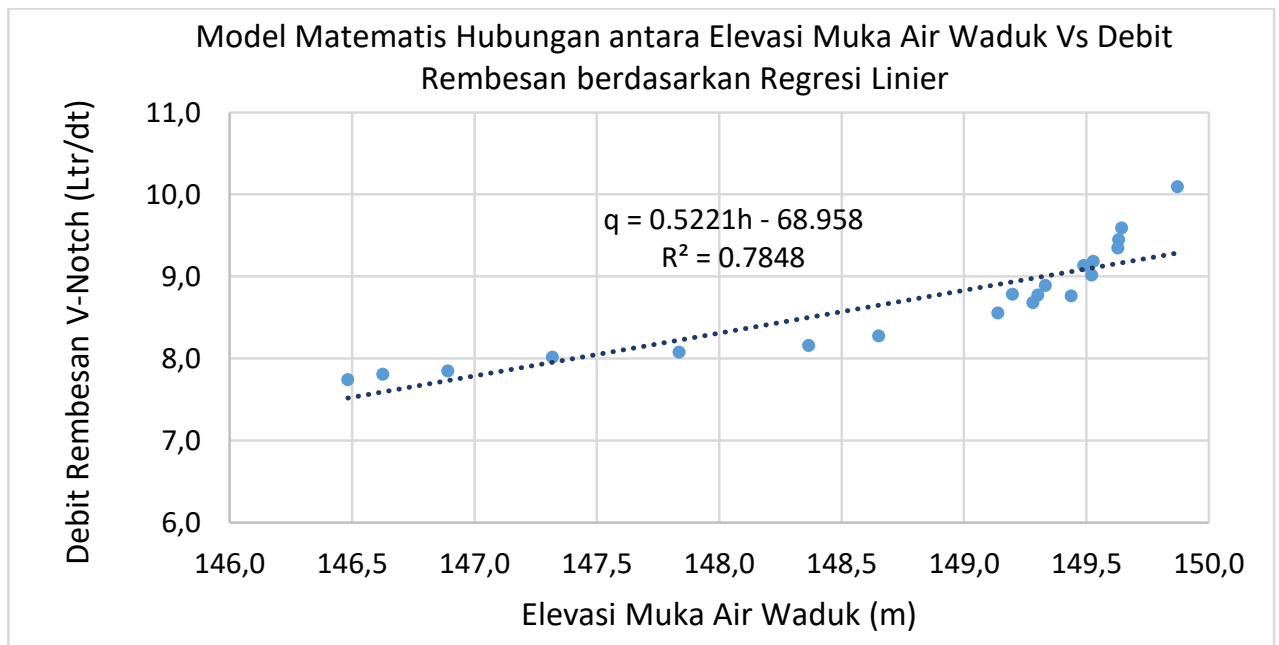

Gambar 8. Regresi Linier Hubungan Antara Debit Rembesan dengan Elevasi Muka Air Waduk 


\subsection{Pemanfaatan model matematis}

Debit yang terukur melalui instrument V-Notch dan metode estimasinya berdasarkan model matematis ini dapat digunakan sebagai acuan dan validasi pemodelan rembesan lainnya dengan pertimbangan sebagai berikut:

- Debit rembesan terukur melalui V-Notvh merupakan debit nyata dimana semua faktor yang mempengaruhi rembesan tercermin dalam kuantitas debitnya.

- Keamanan bendungan terhadap bahaya rembesan mensyaratkan bahwa debit rembesan maksium adalah 2-5\% limpasan[14]. Desain rembesan Bendungan Jatibarang maksimum sebesar $2 \% \times 1.9 \mathrm{~m} 3=38 \mathrm{~m} 3 / \mathrm{dt}$ [11]. Sedangkan rembesan yang terjadi pada elevasi +149.87 sebesar 10.09 ltr/dt. Berdasarkan evaluasi tersebut, debit rembesan pada Bendungan Jatibarang masih dalam batas ambang normal.

- Debit V-Notch merupakan output sedangkan pemodelan merupakan proses. Oleh sebab tersebut, akan lebih mudah untuk melakukan rekayasa (engineering) dan perbaikan (correction) terhadap model pada setiap tahap yang diinginkan.

\section{KESIMPULAN}

Berdasarkan analisis dan pembahasan dapat disimpulkan bahwa: debit rembesan terukur sampai dengan tiga tahun setelah penggenangan belum konsisten dan tidak mempunyai pola yang jelas. Pola yang konsisten didapat setelah bendungan beroperasi diatas tiga tahun. Model matematis hubungan antara elevasi muka air waduk (h) dengan debit rembesan (q) adalah $\mathrm{q}=0.5221 \mathrm{~h}-68.958$. Model matematis ini mempunyai koefisien korelasi positif sebesar 88.6\% yang mengindikasikan bahwa terdapat hubungan yang sangat kuat antara elevasi muka air dengan debit rembesan yang terjadi. Koefisien determinasi pada model tersebut sebesar $78.48 \%$ yang mengindikasikan bahwa model matematis yang didapat mempunyai tingkat kecocokan yang baik terhadap nilai terukur.

\section{DAFTAR PUSTAKA}

[1] Washington Departemen of Ecology, Dam Safety Guidelines. Washington D.C., 2005.

[2] M. D. Azdan and C. R. Samekto, "Kritisnya Kondisi Bendungan di Indonesia," in Seminar Nasional Bendungan Besar Indonesia, 2008, no. July 2008.

[3] A. Ishbaev, N. H. Pandjaitan, and E. Erizal, "Evaluation of Jatilubur Dam Safety Based on Risk Index Tools," J. Nat. Resour. Environ. Manag., vol. 4, no. 2, pp. 111-118, 2016.

[4] U. C. Sari, S. P. R. Wardani, Suharyanto, and W. Partono, "Analisis Tekanan Air Pori Menggunakan Metode Elemen Hingga Dengan Pemodelan Mohr-Coulomb Pada Plaxis," in Konferensi Nasional Teknik Sipil 10, 2016, pp. 675-683.

[5] P. S. Wulandari and D. Tjandra, "Analisis Pengaruh Fluktuasi Muka Air Waduk terhadap Stabilitas Lereng Waduk Dengan Menggunakan Program Plaxis 2D," Media Komun. Tek. Sipil, vol. 24, no. 2, pp. 113-121, 2019.

[6] Suprapto, A. Husna, and A. Taufiq, "Under seepage analysis deduced by multiple methods: instrumentation, modeling, and bydrogeochemistry, in Krenceng Dam, Cilegon, 
Indonesia," in Seminar Pembangunan dan Pengeloaan Bendungan 2018, 2018, pp. 1-10.

[7] Alex and Varughese, "Application of Remote Operated Vehicle as a Post Construction Instrumentation for an Existing Dam- A Case Study," Int. J. Latest Technol. Eng., vol. V, no. IV, pp. 813, 2016.

[8] H. Moayedi, B. B. K. Huat, F. Moayedi, T. A. M. Ali, and A. A. Moghaddam, "23 Years Water Level Monitoring Through Earthfill Dam (Case Study)," Electron. J. Geotech. Eng., vol. 16, pp. 41-58, 2011.

[9] A. . Chavan and S. . Valunjkar, "Dam Instrumentation in Gravity Dams: A Case Study on Koyna Dam," Int. J. Eng. Tech. Res., vol. 3, no. 5, pp. 40-45, 2015.

[10] E. Fathi and M. Golestan, "Considering of Instrumentation Performance Results in
Soil Dams and comparing with Numerical Analysis: a case study on Doosti soil dam in Iran," Electron. J. Geotech. Eng., vol. 22, no. Bund 07, pp. 1-22, 2017.

[11] CTI Engineering International, "Design Review Report Jatibarang Multipurpose Dam," Semarang, 2008.

[12] Ismiyati, Statistik \& Probabilitas Untuk Teknik Bagi Peneliti Pemula. Semarang: Magister Teknik Sipil Universitas Diponegoro, 2011.

[13] A. G. Asuero, A. Sayago, and A. G. González, "The Correlation Coefficient: An Overview," Crit. Rev. Anal. Chem., vol. 36, no. 1, pp. 41-59, Jan. 2006.

[14] Soedibyo, Teknik Bendungan. Jakarta: Pradnya Paramita, 1987. 